Journal of Teacher Education for Sustainability, vol. 21, no. 1, pp. 76-87, 2019

\title{
Trust in the Acquisition of Life Experience of Children Left without Parental Care
}

\author{
Maritana Gorina and N̦ina Šukste \\ Daugavpils University, Daugavpils, Latvia
}

\begin{abstract}
The children's trust determines the relationship between various nuanced emotions and the general attitude towards themselves and the world. Children left without parental care are already subjected to negative experience from childhood, which creates a basic mistrust in people and the world. They have experienced psychological trauma, and often not only one. The authors consider this issue to be topical since children who are left without parental care lose their foundation of trust, and they do not develop productive relationships with their fellow human beings and are unhappy because these children have lost confidence during their life experience. Children who are left without parental care often have to change their living conditions from crisis centres and boarding schools to orphanages and, at best, they are immediately placed in a foster home. These children live in fear because experience shows that they often have to separate from the person they trusted, which has a persistent impact on the child in the process of acquiring a sustainable life experience. Trust builds on the quality of past life experience, relationships with relatives, other adults, friends, foster family, and other stakeholders. Trust is very important. It is very difficult to create deep trust, but very easy to break its fundamental basis. For children who are left without parental care, trust means the belief that the world and people are predominantly good, and the belief that they are good for this world. For the action research, the authors chose a target sample of respondents that interacted with the research, action, and evaluation and comparison of the results obtained in order to find out how the phenomena of trust affected the acquisition of future life experience by children left without parental care.
\end{abstract}

Keywords: children without parental care, trust, foster family, sustainability, life experience, action research.

\section{Introduction}

Living in the Anthropocene age, where people are less and less aware of each other, their relationships lack love. Often young people are establishing families, but the family as such has no value anymore. Children's parents are focused on survival, and therefore their relationships with children are becoming more fragile, and family members lack the warm relationships. It should be noted that social "diseases" are 
becoming more common, such as alcoholism, drug addiction, and children are the direct victims of these social phenomena. Children are at risk of entering the state system from an early age.

Back in history, children were considered orphans if for some reason their parents died and the children had no connection with other relatives. Nowadays, in accordance with Article 1(2) of Protection of the Rights of Child Law, a child left without parental care is a child, whose parents are not known, are missing, or due to a long-term illness are not able to exercise protection or whose parents have had the custody rights discontinued or removed (Saeima, 1998). However, if an accident has occurred with the child's parents, there is love from other family members, relatives who are able to take care of the child. Unfortunately, it does not happen often in Latvia. Children who are left without parental care are defined by the authors of the paper as "social orphans". It is a direct sign of unsustainability, a child's idea that has been noticed too late. Humaneness disappears. This means that children who are left without parental care have parents and relatives who are unable to bring them up. Therefore, the state is responsible for upbringing, doing its best to improve the child's well-being that allows the child to stay away from home. The authors consider that it is an issue of Anthropocene age, which influences not only climate change on a global scale, but also relations among people and all kind of interrelations (Millett, 2015).

Anthropocene's age as the frame of reference (Fedosejeva et al., 2018; Salite, 2015; Salite et al., 2016) allows investigating more complex concepts. Therefore, investigations of its unsustainability issue need more holistic concepts with focus on interrelated and intermingled contexts such as complementarity of nature and human co-evolution, which provides "kumatoid" concept exploration (Salite, 2015; Zuev, 2002). For instance, if we consider "a family" and "a foster family" as the structures where a child's development is simultaneously going on with the establishment of his relationships, so this development process should be necessarily viewed in time dimension. Furthermore, the results of this intermingle are hardly to be predicted. Here comes a similarity to the idea of kumatoid studied by Mihail Rozov (Розов, 2006), who determined the conformity based on the paradigm of modern science that coincides with contemporary needs and expectations ( ̌́witala, 2015).

At the initial stage of trust research as well as the essence of its phenomenon, first, it is vitally important to look at the notion of the family and the foster family through the prism of kumatoid's metaphor and types. From this point of view, we will look at the kumatoid as an environment that enables the child's activities, actions and development necessary for the natural development and manifestation of his/her personal potential. There are specific differences in the biological family and the foster family, but in a general sense they can be seen as kumatoids. They are similar in their functions, although the child's relations to one are based on the biological commitment to the family, a wider species and cultural human commitment. According to Rozov's theory, both a foster family and a biological family may also be a kumatoid, which changes via activity and actions inside these fundamental structures (Розов, 2012).

A family in educational research can be investigated in a broader sense as the kumatoid, which is open to virtues and dominant influences of Anthropocene and can be investigated in the current frame of Anthropocene with unsustainable relations in society and need to renew society by development of the mission-oriented pedagogy (Salite, 2015) and sustainable family pedagogy for children without parental care. In 
terms of holistic nature of kumatoid as a complex interrelated and intermingle phenomenon or notion, this is the high priority for society, pedagogy and education sphere. The goal of this challenging educational research is to develop a really transdisciplinary perspective (Fedosejeva et al., 2018; Salìte et al., 2016) and create life conditions with an emphasis on spirituality and a person's spirituality, which will be revealed during the life conditions and realised via life actions (Salite, 1998). In the present research, the highlighted phenomenon of trust is related and dependent on the effects of external and internal human environment, especially in the current destructive Anthropocene era. The authors have focused on exploring the current understanding of the idea of a foster family in a broader perspective, where it is important not to lose the holistic understanding of this idea as the fundamental base of human integrity. It affects the individual's personal development, his/her relationship with the world as a whole, and his/her engagement with a foster family and society. All this can be rather helpful in finding and understanding the role of trust in spirituality.

Abraham Maslow (2011), Marija Osorina (2010), and Jean Liedloff (2003) indicate that, based on trust, the child has a positive attitude towards him/herself (I love, it means that I am good); the child is able to trust, properly assess his/her abilities (adequate self-esteem), as well as has initiative. According to American psychologist Carroll Izard (2011), trust is a hidden message without showing that one cares for the interests of others. Therefore, a child can perceive criticism and does not become angry with the people whom he/she trusts (Izard, 2011). Therefore, in the heart, the child realises that one is willing to help him/her. Being appreciated by an adult who treats him/her with confidence and respect is of particular importance for a child. Once lost, trust is very difficult to regain. Trust in life for a child becomes the basis for optimism, the belief that life is valuable, despite failures.

The goal of the research is to find out the phenomena of trust of children left without parental care and their role in acquiring a sustainable life experience. In this case, trust is seen as a lifetime, dynamic phenomenon of experience that has been initially developed in the biological family and/or in a foster family which, in its turn, is influenced by the society.

\section{Method}

\section{Participants}

The research was launched in October 2018. Twenty $(n=20)$ respondents - children left without parental care - participated in the research.

\section{Procedure}

The study is based on the quantitative and qualitative methods, which have been used in the framework of open action research. Although action research in terms of trustworthiness and strength is sometimes considered weak and vague, it allows researching complex and nonlinear processes especially in education (Kapenieks, 2016; Salite et al., 2016). The use of different research methods made it possible to better understand the problem under consideration, as well as increased the reliability of the research results. Qualitative methods have been used for interviews with children left without 
parental care, for the analysis of their life experience, as well as for the analysis of normative documents. Quantitative methods have been used to carry out a survey of children left without parental care on the separation from persons whom they trusted at their life experience stages and the ability to rely on another person or the world as a whole. The combination of both information acquisition and analysis approaches (qualitative and quantitative) eliminates imperfections that are inevitable when using only one method. For example, the results of interviews with children left without parental care allow for a deeper understanding of their life experience stages, of the people they trusted or did not trust, as well as possible ways of solving the problem that can determine the factors that may affect and have affected the acquisition of their sustainable life experience. A target sample of respondents has been chosen for the action research, which established interaction between the research, action, and the evaluation and comparison of the results obtained (Mārtinsone \& Pipere, 2011). Mathematical statistical data processing methods have been used for data processing - generic sets and sample sets for the processing of characteristics and evaluation of the obtained results. The primary mathematical statistical data processing method directly reveals the results of the research implemented in tables and in MS Excel 2007 software. For transparency, data are interpreted graphically in diagrams.

\section{The Trust Issue in Anthropocene Age Society}

In today's society, the question of trust or distrust is raised too often, forcing the public to devote their attention to it and indicating the topicality of the issue. In Latvia, especially in social networks, a lot of discussions and conversations were triggered by the Festival of Negotiations "LAMPA" being entirely devoted to the topic of trust, which was held in June 2018 in Cēsis. On the European scale, much fear and hope are caused by the future British exit from the European Union.

This is a natural need that every person is looking for a sense of trust and it helps everyone find and, to some extent, understand the phenomenon of trust. The concept of trust is so versatile, depending on a particular science that defines it. Philosopher Russell Hardin (2002) defines trust as "encapsulated interest in which the trustee's expectations of trustworthy behaviour depend on rational assessments of the trustee's motivations".

Psychologists emphasise the emotional component of trust, underlining that trust is "an emotional state of the brain, not just a behaviour" (Thagard, 2019).

Trust, from the pedagogical point of view, is based on "the belief of the learner, the confidence that he/she is able" (Ricci \& Pritscher, 2015).

If an educator is willing to base his/her activities on trust, it will require not only a change in his/her teaching, but also the inclusion of trust as a basic principle in his/her curriculum. In short, it can be concluded that the reality of trust is rather heterogeneous and non-linear. However, it is worth our attention because our daily actions are based on our decision to trust or not.

Being aware of the phenomenon of trust, the second question arises about the possibility of learning to trust. Robert Solomon and Fernando Flores in their book "Building Trust: In Business, Politics, Relationships, and Life" emphasise the idea that trust is not what we have for entire life, trust can and even need to be taught and learned (Solomon \& Flores, 2001). Thus, trust helps build not only meaningful relationships with others, but it is also closely related to knowledge and freedom. 
This kind of learning in a foster family is becoming an environment, in which trust forms and develops, which is an essential context for children left without parental care. Trust is an issue that needs to be seen as a central phenomenon in these circumstances.

\section{Some Signs of Life Experiences of Children Left Without Parental Care}

Children left without parental care staying in orphanages, boarding schools, outside their family are still a problem in the $21^{\text {st }}$ century. Their development and health have several influences that are observed at all stages of their lives - from infancy to adolescence and also later in life. If a child was ever lacking mother's attention and love, it manifested in a later period of life.

Every child needs a family environment in order to build a life experience as mentioned in works by authors of human and holistic pedagogy, as well as philosophers. Janusz Korczak was also interested in the issue of upbringing of children; the scholar was influenced by the ideas and experiences of "new upbringing". Korczak was inspired by John Dewey's progressive educational theory, as well as by works of Decroly, Montessori, Pestaloci, Spencer, Froebel etc. (Lewowicki \& Korczak, 1994). In his theory, Dewey offered an evolutionary ontological perspective in explaining the experience by extending the ontological perspective to understanding the roots of education. Dewey stated that personality development in the course of life depended on the type and quality of the experience the person participated in. Dewey distinguished the characteristic feature of experience: its limitation in time. An ontologically broader perspective opens up the opportunity to understand and develop a deeper understanding of the opportunities for society to perceive the causes and consequences of trust and distrust phenomenon, which is one of the key issues in foster family pedagogy.

Korczak maintains, there are no children, there are people, but with other thinking, with other experiences, with other tendencies, with different expression of feelings... (Korčaks, 1989, p. 19).

In the Second World War, thousands of children lost their parents; they were left without home, care, parents' love and upbringing. At that time, the medical student Hermann Gmeiner (2002) was convinced that a family environment gave children a much better foundation on which to build a future life than an orphanage. After the war in 1949, Gmeiner built the first Children's Village for orphans and abandoned children in Imst, Austria (SOS Children's Villages).

The authors in their research examine the life experiences of children left without parental care from birth to eighteen years of age. All of them have a different life experience, except only one similar feature that they all have living parents. Let us find out what is meant by the concept of a biological family or birth family (BF); in German Herkunftsfamilie (AkadTerm, 2018). Biological family is made up of individuals who only have blood relations. Biological parents, whatever they want, but not always manage to keep a family where a child has a secure feeling that is the basis for further confidence and trust.

On the basis of Section 22 of the Law on Orphan's and Custody Courts, when the child custody of a parent is discontinued or removed, the child is removed from the biological family, and the path of his/her life experience (LE) begins and it is different 
for each child and no one knows how and where the child will develop his/her future life experience.

The authors explain where the children go after their removal from the biological family. The first service providers are the orphanage $(\mathrm{O})$, crisis centre $(\mathrm{CC})$ or boarding school (BS) - a residential school where pupils study and live.

Orphanage is an institution that meets the needs of society in terms of culture, healthcare or social security (Latvian Oxford Living Dictionaries, 2019).

Section 1(8) of the Law on Social Services and Social Assistance states that the crisis centre is a social institution where short-term psychological and other types of assistance are provided to persons in a crisis situation (Saeima, 2003).

Foster family (FF) is a family that ensures care for a child who has been temporarily or permanently removed from his or her family environment or in whose interests remaining in his or her family is not permitted until the moment when the child may return to his or her family or, if that is not possible, is adopted, guardianship has been established (State Inspectorate for Protection of Children's Rights).

Foster families should implement a holistic approach to develop personality of children left without parental care. The holistic approach to personality development and upbringing envisages that a person can live a harmonious life if $\mathrm{s} / \mathrm{he}$ has developed all areas of life equally: mental, intellectual, physical and emotional. If the foster parents achieve that the child trusts them, they can talk about building of a sustainable life experience.

When it comes to foster families, it should be taken into account that their biological children also live in the family. The foster family should certainly take into account the relationship between their children and the adopted children who have been left without parental care. Exactly foster parents take charge of raising children left without parental care, children who have experienced the absence of a mother figure, the lack of love and attention, by following a full-fledged personality development based on trust in the surrounding world.

Personality traits of foster parents (FP) are the defining qualities of the future of children, as practically all children who live in social care institutions, whether they are from an orphanage or boarding school, have deviations in emotional, physical, or mental development, which definitely influence their behaviour; therefore, foster parents have to put in a lot of effort and wisdom to form favourable contact with such children.

At birth, the child is just an "opportunity". The child grows and changes, and in this respect it cannot be considered that the child will keep its natural essence intact because time, events, and life experience have an impact on children's feelings, experiences, needs, thus creating unique character and personality.

\section{Results}

The research is based on 20 respondents (10 men and 10 women); the average age of respondents is 20 years - these are the children left without parental care at the age of majority who already live independently. Every respondent has experienced his or her own way of life. In the context of the research, it has been important to find out how many years the child lived in a biological family and his/her subsequent life stages to adulthood. The data are shown in Table 1. 
Table 1

The Stages of Life Experience of Children Left without Parental Care $(n=20)$

\begin{tabular}{|c|c|c|c|c|c|c|c|c|c|}
\hline 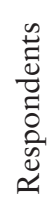 & 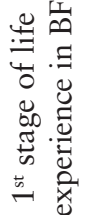 & 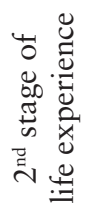 & 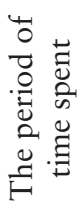 & 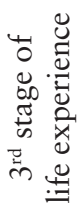 & 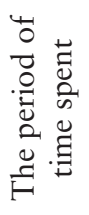 & 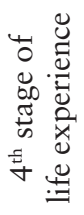 & 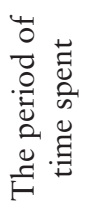 & 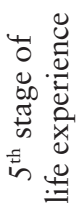 & 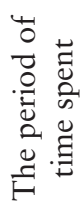 \\
\hline
\end{tabular}

\begin{tabular}{cccccccc}
\hline 1. & Up to 5 & CC & 1 year & BS & 1 year & FF & 11 years \\
\hline 2. & Up to 8 & CC & 1 year & CC & 1 year & FF & 8 years \\
\hline 3. & Up to 9 & BS & 3 years & CC & 2 years & FF & 4 years \\
\hline 4. & Up to 9 & BS & 3 years & CC & 2 years & FF & 4 years
\end{tabular}

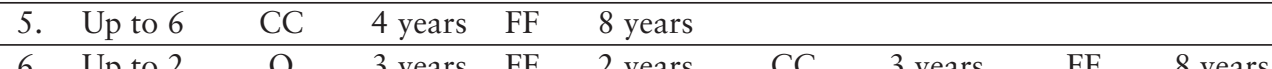

7. Up to 14 CC 1 year FF 1 year CC 2 years

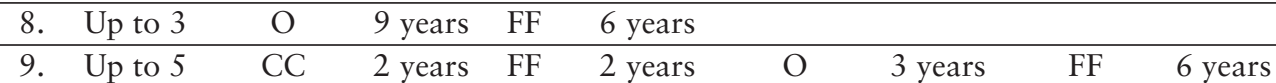

10. Up to 6 O 9 years FF 3 year

\begin{tabular}{cccccccccc}
\hline 11. & Up to 7 & BS & 4 years & CC & 6 months & FF & 3 years & Adoption & USA \\
\hline 12. & Up to 7 & BS & 4 years & CC & 6 months & FF & 3 years & Adoption & USA \\
\hline 13. & Up to 12 & Relatives & 1 year & O & 3 years & FF & 2 years & &
\end{tabular}

14. Up to 13 CC 1 year FF 4 years

15. Up to 2 O 2 years FF 4 years Adoption

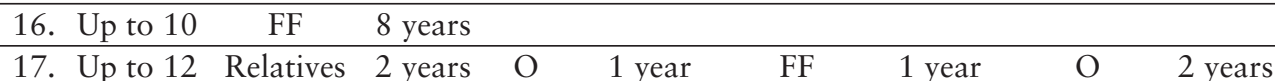

\begin{tabular}{llllll}
\hline 18. & Up to 16 & FF & 2 years & & \\
\hline 19. & Up to 13 & CC & 2 years & FF & 3 years \\
\hline 20. & Up to 11 & CC & 3 years & FF & 4 years
\end{tabular}

Notation: BF - biological family, CC - crisis centre, BS - boarding school, $\mathrm{O}$ - orphanage, FF foster family.

The data collected show that each of the respondents has their own path of life experience. At best, those children left without parental care are successful who come to the foster family right away. In our study, only two respondents experienced such a situation. The rest had to live in orphanages, crisis centres and boarding schools. It can be seen that the period of their stay was different for each respondent. The time spent by respondents in the biological family also varied from 2 to 16 years.

Figure 1 shows the stages of life experience of children left without parental care. Undoubtedly, every child from birth has his/her biological parents. Within the framework of the research, it has also been proven that $100 \%$ of children had their first life experience in their family. Due to different life situations (violence against the child, no care for the child), the children are removed from their biological family, and the next stage of life experience begins for the children. Of course, this stage is different for every child; out of 20 respondents who participated in the study, $40 \%$ came to the crisis centres, $20 \%$ to orphanages and $20 \%$ to boarding schools. $10 \%$ of respondents stayed with their relatives and $10 \%$ came to foster families. Out of 20 respondents, 18 respondents underwent the $3^{\text {rd }}$ stage of life experience, changing the environment, seeking for shelter, pro- 
tection, and comfort. $56 \%$ of respondents came to foster families, $28 \%$ to crisis centres, $11 \%$ to orphanages, and $5 \%$ to boarding schools. The $4^{\text {th }}$ stage of life experience was undertaken by 12 out of 18 respondents, $67 \%$ of whom came to foster families, $17 \%$ to crisis centres, $8 \%$ to orphanages and $8 \%$ were adopted. The 5 th stage of life experience was undergone by 5 respondents, $40 \%$ of whom came to foster families, $40 \%$ were adopted and $20 \%$ came again to orphanages. Children left without parental care have a difficult and complicated way of life, constantly changing the usual circumstances, people around them. Children lose faith that at times when support will be needed, they will receive it, on the contrary - they expect to be rejected. Data are shown in Figure 1.

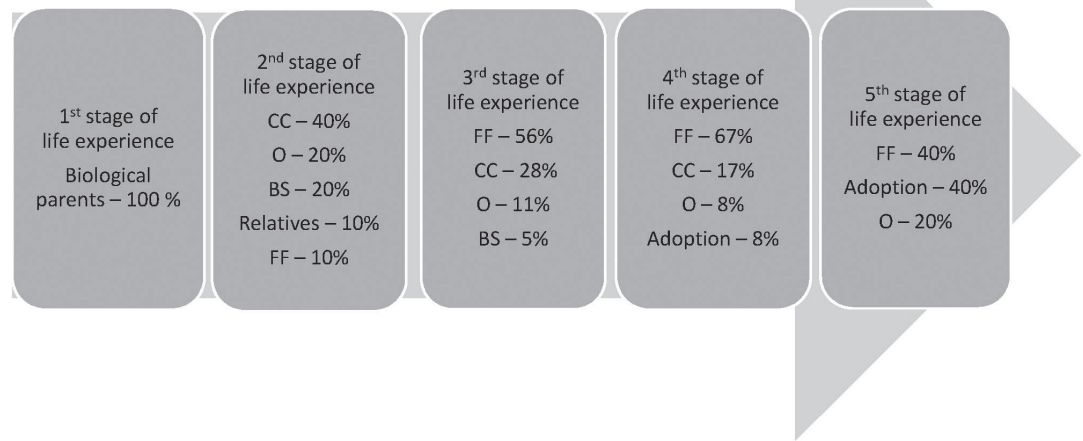

Figure 1. The stages of life experience of children left without parental care $(\mathrm{n}=20)$

Here are some examples of the respondents' life experience:

Edgars (24) - The biological mother gave up the child when he was 2 years old. The child came to the orphanage. When Edgars was 4 years old, he was taken by FF. The boy stayed in the family for 4 years and he was happy, then the foster mother became seriously ill and the FF had to give up the boy. Edgars again came to the orphanage until he was taken again by a new FF. When Edgars was taken by a new FF, the boy was already 10 years old. Edgars had problems at school with learning and behaviour. The boy repeated the grade twice. When he was 16 years old, Edgars had a conflict with the FF, after which the FF gave up Edgars, bringing him to a crisis centre. Edgars realised that he did not want to live in the crisis centre, but wanted to successfully finish school. He addressed his teacher, whose family had the status of foster family to take him to the FF. Thus, Edgars at the age of 16 years came to the FF. The boy finished grade 9 when he was 18 years old. He pursued studies and became a waiter. Now he has a good job. He is married and has a daughter. He regularly communicates with the FF.

Ritvars (21) was removed from the family when the boy was 14 years old and he came to a crisis centre. The FF was quickly found for Ritvars. The boy had behavioural problems (stealing and roving). For years, the boy was roving, stealing, and spending time with young people of disadvantaged background until he was in the focus of the police. Ritvars was a wise boy but he did not 
want to learn. In the FF, his behaviour was good, but out of house, he started misbehaving. Several times he stole. He smoked, tended to use alcohol. He regularly lied. He could not explain his behaviour. The boy's goal was to get to the prison; he explained it by the fact that only strong men came out of prison. When the boy finished the secondary school ( $9^{\text {th }}$ grade), the FF gave him up. Ritvars came to a crisis centre. The boy's behaviour did not improve, he continued to rove, steal. School teachers could not cope with Ritvars; he was committed to be imprisoned. And his wish came true, the boy committed several offences and got imprisoned in the colony.

Each of the 20 respondents who participated in the study has their own life story, their own experience, which is successful and unsuccessful. Continuing the research, the authors have identified whether during the stages of life experience they had to separate from the person they trusted and could rely on. The obtained data show that 20 respondents had to lose their trustee (the trusted people) 42 times, and 32 respondents formed basic mistrust because deliberately and sometimes unintentionally they avoided establishing a lasting relationship, tried to survive without love and support from other people. Data are shown in Figure 2.

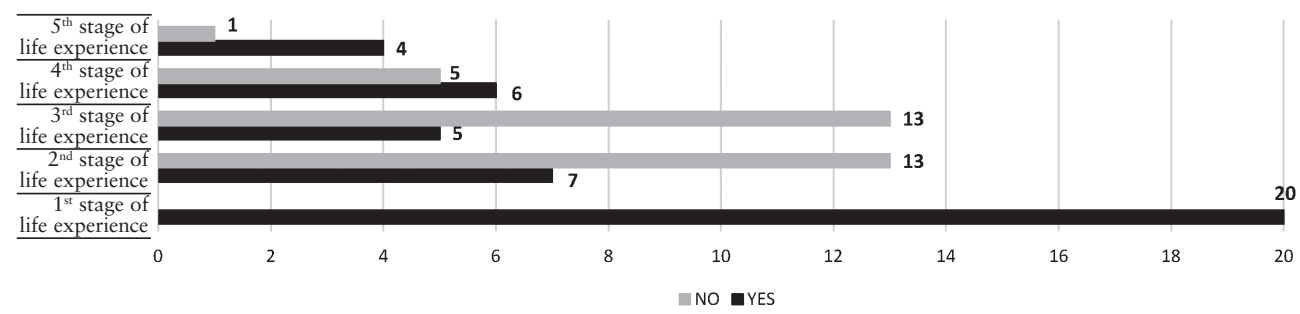

Figure 2. Respondents' replies regarding separation from the person they trusted $(\mathrm{n}=20)$

In the context of the research, it has been important to find out the respondents' opinion on what qualities a person should have to trust him/her. Data are shown in Table 2.

Table 2

The Qualities of a Person to Trust Him /Her

\begin{tabular}{lrr}
\hline The ability to understand me & 3 & $15 \%$ \\
\hline Rich life experience and wisdom & 3 & $15 \%$ \\
\hline Fulfilment of promises and the one who does not deceive & 4 & $20 \%$ \\
\hline Generosity & 2 & $10 \%$ \\
\hline Common interests & 2 & $10 \%$ \\
\hline Support & 0 & $0 \%$ \\
\hline Spending time together & 1 & $5 \%$ \\
\hline Good adviser & 0 & $0 \%$ \\
\hline Ability to keep secrets & 3 & $15 \%$ \\
\hline Caring & 0 & $0 \%$ \\
\hline Fair & 1 & $5 \%$ \\
\hline Good adviser & 0 & $0 \%$ \\
\hline Helps gain a life experience & 1 & $5 \%$ \\
\hline Responsible & 0 & $0 \%$ \\
\hline Total replies submitted & 20 & \\
\hline
\end{tabular}


Within the framework of the research, it has been important to find out the most important characteristics that the children left without parental care took over from the person they trusted during the accumulation of their life experience. The collected data on the aspects of trust/distrust in terms of sustainability demonstrate that the main aspects mentioned by the respondents are honesty, love, good nature and care for their fellow human beings. Five respondents do not trust anyone because their hope did not correspond to the reality of life. The other answers contained: fulfilling one's responsibilities and treating one's fellow human beings politely; good attitude; honesty and achievement of the chosen goals; honesty and order in things; fulfilling one's household duties, being accurate and honest; achieving something in life - it is necessary to learn much, to work and be honest; I did not trust anyone, relied solely on myself; I learned a lot from foster parents. All one needs to live independently; to know how to care for children; I do not trust anyone; good nature and love towards fellow human beings; love towards people; help the weak; nothing; it is not good to drink alcohol; take care of one's family; I do not trust anyone - everyone is lying around; I only trust myself and my friends; I do not trust anyone, I live as I want; I trusted my parents, and they deceived me, and now I do not trust anyone.

Paying attention to the fact that most of the respondents who participated in the research had to experience a frequent change of the environment, fellow human beings, the conditions, it is not surprising that the children left without parental care do not have the ability to trust, if they had experienced that life was cruel to them. The existence of "social orphan" in this world already means that they have a relationship with it. Children come to a situation that they cannot choose by themselves. Parents, familiar and unfamiliar people, as well as all objects and animals are part of the world which a child enters. Relationship with the world is mainly about understanding the rules of the game, called life. By trusting someone, the children learn to live, improve the quality of their lives, looking for ways to gain a sustainable life experience.

\section{Conclusions}

Twenty respondents (10 men and 10 women) participated in the study; the average age of respondents was 20 years.

Within the framework of the action research, the stages of life experience of children left without parental care from birth to adulthood have been clarified and there are 5 stages of changing the environment, normal circumstances, and fellow human beings.

The survey found that 20 respondents had to lose their trustee (the trusted people) 42 times, and 32 respondents formed basic mistrust in fellow human beings.

The research enabled to answer the question: "What qualities should a person have to be able to trust him/her?" From the respondents' perspectives, it can be concluded that the key aspect is the fulfilment of promises and the person who will not deceive, the ability to keep secrets, the rich life experience and wisdom, the ability of the trustee (the trusted people) to understand the child.

The collected data on the aspects of trust/distrust in terms of sustainability demonstrate that the components of trust are openness, frankness, sincerity, honesty, the ability to keep promises, benevolence and respect. However, if there is mistrust, then the child is led by different fears, distrust in the world and fellow human beings. 


\section{References}

Akadēmiskā terminu datubāze AkadTerm. (2018). [Academic terminology database AkadTerm]. Available: http://termini.lza.lv/term.php?term=biolo\%C4\%A3isk\% C4\% $81 \% 20 \%$ C4\%A3imene\&list=\%C4\%A3imene\&lang=LV

Bērna aizgādības tiesību pārtraukšana, atņemšana un atjaunošana. (01.01.2007). [Suspension, withdrawal and renewal of custody of a child]. Published: Latvijas Vēstnesis, 107 (3475), LR Saeimas un MK Ziṇotājs.

Bèrnu tiesību aizsardzības likums. (22.07.1998). [Child rights protection law]. Published: Latvijas Vēstnesis, 199/200 (1260/1261), LR Saeimas un MK Ziṇotājs.

Fedosejeva, J., Boče, A., Romanova, M., Iliško, Dz., \& Ivanova, O. (2018). Education for sustainable development: The choice of pedagogical approaches and methods for the implementation of pedagogical tasks in the Anthropocene age. Journal of Teacher Educational for Sustainability, 20(1), 157-179.

Gmeiners, H. (2002). Founding the first SOS Children's Village. The umbrella organisation of SOS Children's Villages. Available: https:/www.sos-childrens villages.org/ who-we-are/history/hermann-gmeiner

Hardin, R. (2002). Trust and trustworthiness. New York: Russell Sage Foundation.

Kapenieks, J. (2016). Educational action research to achieve the essential competencies of the future. Journal of Teacher Education for Sustainability, 18(1), 95-110.

Korčaks, J. (1989). Kā mìlèt bèrnu? [How to love a child?] Rìga: Zvaigzne.

Latvian Oxford Living Dictionaries. (2019). Available: https://lv.oxforddictionaries.com/ definition/NAMS. Oxford: Oxford University Press.

Lewowicki, T., \& Korczak, J. (1994). Prospects: the quarterly review of comparative education (Paris, UNESCO: International Bureau of Education), vol. XXIV, no. 1/2, 1994, p. 37-48.

Mārtinsone, K., \& Pipere, A. (red.). (2011). Ievads pētniecībā. Stratēgijas, dizaini, metodes. [Introduction into research. Strategies, designs, methods]. Riga: Raka.

Millett, D. (2015). Anthropocene: The age of man. North Charleston: A DBA or OnDemand Publishing LLC.

Ricci, C., \& Pritscher, C. P. (2015). Holistic pedagogy: The self and quality willed learning. Springer.

Salite, I. (1998). An ecocentric paradigm: An important tool for teachers of environmental education. Australian Journal of Environmental Education, 14, 81-85.

Salīte, I., (2015). Searching for sustainability in teacher education and educational research: experiences from the Baltic and Black Sea Circle Consortium for educational research. Discourse and Communication for Sustainable Education, 6, 21-29.

Salìte, I., Drelinga, E., Iliško, Dz., Oḷehnoviča, E., \& Zariņa, S. (2016). Sustainability from the transdisciplinary perspective: An action research strategy for continuing Education Program Development. Journal of Teacher Education for Sustainability, 18(2), 135-152.

Sociālo pakalpojumu un sociālās palīdzības likums. (01.01.2003). [Social services and social assistance law]. Published: Latvijas Vēstnesis, 168 (2743), LR Saeimas un MK Ziņotājs.

Solomon R. C., \& Flores, F. (2001). Building trust: In business, politics, relationships, and life. Oxford: Oxford University Press.

Špona, A., \& Čehlova, Z. (2004). Pètniecība pedagogìīa. [Research in pedagogy]. Rīga: Raka. 
Šwitala, E. (2015). Teachers' values related to sustainable development in Polish and Latvian secondary schools. Discourse and Communication for Sustainable Education, 6, 127-131.

Thagard, P. (2019). Mind-society: From brains to social sciences and professions. Oxford: Oxford University Press.

Valsts bērnu tiesību aizsardzības inspekcija. Kas ir audžuǵimene? [The State Inspectorate for protection of children's rights. What is a foster family?] Available: http://www. bti.gov.lv/lat/arpusgimenes_aprupe/audzugimene/?doc $=1920$

Zuev, V. (2002). The problem of reality in biological taxonomy. Novosibirsk: Novosibirsk University Publisher.

Изард, К. Э. (2011). Психология эмоций. [Psychology of emotions]. СПб.: Питер.

Ледлофф, Ж. (2003). Как вырастить ребенка счастливым. Принцип преемственности. [How to raise a child happy. The principle of continuity]. Москва: Генезис.

Маслоу, А. (2011). Мотивация и личность. [Motivation and personality]. СПб.: Питер.

Осорина, М. В. (2010). Секретный мир детей в пространстве мира взрослых. 5-е изд. [The secret world of children in the space of adults' world]. (5 $5^{\text {th }} \mathrm{Ed}$.). СПб.: Питер.

Розов, М. А. (2012). Философия науки в новом виденни. [The new picture of philosophy]. Москва: Новый хронограф. Available at http://berezkin.info/wp-content/ uploads/2015/03/Rozov-Filosofija-nauki-v-novom-videnii_pdf.pdf

Розов, М. А. (2006). Теория социальных эстафет и проблемы эпистемологии. [The theory of social relay race and the problems of epistemology]. Смоленск: Смоленский государственный педагогический университет.

Correspondence concerning this paper should be addressed to Maritana Gorina, doctoral student, Daugavpils University, Parādes iela 1, Daugavpils, LV-5401, Latvia. Email: gorina@inbox.lv 